\title{
Algılanan Sosyal Destek ve Bilişsel Duygu Düzenleme ile Duygusal Tepkisellik Arasındaki İlişkilerin İncelenmesi
}

Examining the Relationships Between Perceived Social Support and Cognitive Emotion Regulation and Emotional Reactivity

\section{Özlem ÇAKMAK TOLAN ${ }^{[1]}$ Serdem Benan TÜMER ${ }^{[2]}$ Ezgi Dilan YILDIRIM[3]}

Başvuru Tarihi: 01 Aralık 2021

Kabul Tarihi: 08 Şubat 2022

Bu araştırmanın amacı, duygusal tepkiselliğin uyumlu ve uyumsuz bilişsel duygu düzenleme ve algılanan sosyal desteğin türlerinden nasıl etkilendiğini ortaya koymaktır. Katılımcılar 262'si kadın (\%65.5), 138'i erkek (\%34.5) 400 üniversite öğrencisinden oluşmaktadır. Araştırmaya ait veriler "Demografik Bilgi Formu”, "Duygusal Tepkisellik Ölçeği”, "Çok Boyutlu Algılanan Sosyal Destek Ölçeği” ve "Bilişsel Duygu Düzenleme Ölçeği” kullanılarak toplanmıştır. Verilerin analizinde t-test, Pearson korelasyon analizi ve çoklu regresyon analizleri kullanılmıştır. Araştırma bulguları, duygusal tepkiselliğin alt boyutu olan tepkiselliğin erkeklerde daha yüksek düzeyde olduğunu ve algllanan sosyal destek, bilişsel duygu düzenleme ve duygusal tepkisellik değişkenlerinin alt boyutları arasında anlamlı ilişkiler olduğunu ortaya koymuştur. Duygusal tepkiselliğin alt boyutlarının yordanmasında aile, olumlu yeniden odaklanma, plana yeniden odaklanma ve olumlu yeniden gözden geçirmenin pozitif bir etkisi olduğu bulunmuştur. Düşünceye odaklanma ve bakış açısına yerleştirmenin ise duygusal tepkiselliğin açıklanmasında negatif bir etkisi olduğu görülmüştür. Sonuç olarak araştırma, duygusal tepkiselliğin açıklanmasında algılanan aile desteğinin ve uyumlu bilişsel duygu düzenlemenin pozitif; uyumsuz bilişsel duygu düzenlemenin ise negatif etkisini ortaya koymuştur. Sonuçlar ilgili alanyazın ışı̆̆ı altında tartışılmış ve öneriler sunulmuştur.

Anahtar Kelimeler: algılanan sosyal destek, bilişsel duygu düzenleme, duygusal tepkisellik

The aim of this study is to investigate how emotional reactivity is affected by adaptive and maladaptive cognitive emotion regulation and perceived social support. Participants consisted of 400 university students, 262 of which were female (65.5\%) and 138 (34.5\%) were male. The data of the study were collected using the "Demographic Information Form", "Emotional Reactivity Scale", "Multidimensional Scale of Perceived Social Support" and "Cognitive Emotion Regulation Scale". T-test, Pearson correlation analysis and multiple regression analyzes were used in the analysis of the data. The findings show that reactivity, a sub-dimension of emotional reactivity, is higher in males and there are significant relationships between the sub-dimensions of perceived social support, cognitive emotion regulation and emotional reactivity. It was found that family, positive refocusing, refocusing on plan, and positive reappraisal had a positive effect on predicting the sub-dimensions of emotional reactivity. Rumination and putting into perspective were found to have a negative effect. In conclusion, the research showed the positive effect of perceived family support and adaptive cognitive emotion regulation strategies and the negative effect of maladaptive cognitive emotion regulation strategies in explaining emotional reactivity. The results were discussed in the light of the relevant literature and suggestions were presented.

Keywords: perceived social support, cognitive emotion regulation, emotional reactivity

Çakmak Tolan, Ö., Tümer, S. B., \& Yıldırım, E. D. (2022). Algılanan sosyal destek ve bilişsel duygu düzenleme ile duygusal tepkisellik arasındaki ilişkilerin incelenmesi. Humanistic Perspective, $4 \quad$ (1), 82-106. https://doi.org/10.47793/hp.1055988

[1] Dr. Öğr. Üyesi | Dicle Üniversitesi | Edebiyat Fakültesi | Psikoloji Bölümü | Diyarbakır | Türkiye | ORCID: 0000-0002-8128-6498 | ozlemtolan@gmail.com [2] Yüksek Lisans Öğrencisi | Dicle Üniversitesi | Sosyal Bilimler Enstitüsü | Klinik Psikoloji | Diyarbakır | Türkiye | ORCID: 0000-0002-8460-5378 [3] Yüksek Lisans Öğrencisi | Dicle Üniversitesi | Sosyal Bilimler Enstitüsü | Klinik Psikoloji | Diyarbakır | Türkiye | ORCID: 0000-0003-4430-8544 


\section{GíRiș}

osyal destek bireylerin kendilerini ait hissettikleri gruplar ve sahip oldukları ilişkiler yoluyla ihtiyaç duydukları sosyal etkileşimleri temin ettikleri bir yapı olarak tanımlanmaktadır (Norris ve Kaniasty, 1996). Cutrano (1996), sosyal desteği bireyin güven, onaylanma ve maddi/manevi kaynaklara dair gereksinimlerinin karşılanması olarak ele almıştır. Sosyal destek algılanan sosyal destek ve alınan sosyal destek şeklinde iki kategoride incelenmektedir. Algılanan sosyal desteğin yüksek olması bireyin ihtiyaç halindeyken gereken yardımı alacağına dair bir inanca sahip olması ile açıklanmaktadır (Ioannou vd., 2019; Lepore vd., 1991; Oktan, 2005). Bireylerin sahip oldukları ilişki ağlarının psikolojik ve fiziksel sağlık açısından önem taşıdığı bilinmektedir. Algılanan sosyal destek, destek kaynaklarının ihtiyaç duyulduğu anda bulunması olup, öznel niteliksel bakış açılarıyla tanımlanıp ölçülebildiği gibi, ruh sağlığı üzerinde algılanan sosyal desteğin alınan sosyal desteğe göre daha belirleyici olduğu belirtilmektedir. (Cunningham ve Barbee, 2000; Reti vd., 2021). Bireyin kişiliği ve başa çıkma tarzlarının algılanan sosyal desteğin derecesiyle ilişkili olduğu söylenebilir (Bruhn ve Philips, 1984; Swickert vd., 2010; Udayar vd., 2020). Cassell (1976) ve Cobb’un (1976) sosyal desteği psikolojik ve fiziksel iyi oluşla ilişkilendirdikleri çalışmalarına kadar bu değişkenler arasındaki bağlantı açıkça ortaya konmamıştır. Sosyal ağlarını destekleyici olarak algılayan insanlar, ağlarını daha az olumlu değerlendirenlere göre zihinsel ve fiziksel olarak daha sağlıklı bulunmuştur. (Agoha vd., 2015; Diaz ve Bui, 2016; Matsuda vd., 2014; Sarason vd., 2000). Aileden algılanan sosyal desteğin psikolojik iyi oluşun bir yordayıcısı olduğu farklı çalışmalarla ortaya konmuştur (Cheng ve Furnham, 2003; Diener ve Fujita 1995; Diener ve Seligman 2002; MacGeorge vd., 2005).

Araştırma bağlamında ele alınan değişkenlerden biri olan duygu düzenleme; kişilerin duygusal deneyimlerini ne zaman, nasıl ve hangi koşulda yaşadığını, duyguların çevresel taleplere göre işlenme süreçlerini ve gerekli durumlarda duygularını ele alıp değiştirilme becerisini ifade etmektedir (Cole vd., 2004; Gross, 1998; Thompson, 1994). Duygu düzenleme, olaylara veya uyaranlara karşı duygusal tepkileri engellemek, dikkati yeniden odaklamak ve bilişsel koşulları yeniden oluşturmak için bu duyguları yeniden düzenleme süreci olarak da düşünülebilir (Suri vd., 2015). Duygusal deneyimlerin belirgin uyaranlara yönelik düzenlemeleri olarak kavramsallaştırıldığında duygu düzenlemenin, hem erken duygusal tepkisellikle hem de daha sonraki duygu düzenleme bileşenleriyle ilişkili olduğu ortaya konmuştur (Gross vd., 2011). Rosen vd. (2012) uyumlu duygu düzenleme stratejilerinin duygusal tepkiselliği düzenlediğini ve duygusal stres üzerinde olumlu bir etkisi olabileceğini belirtmişlerdir. Bu bağlamda, mevcut çalışmada incelenen değişkenlerden biri olan duygusal tepkisellik; bireyin duygusal deneyimlere hazır oluşunu, deneyimlenen duyguya yatkınlığını, duygunun yoğunluğunu ve süresini belirleyen etmenlerden biri olarak kabul edilmektedir (Davidson, 1998; Gohm ve Clore, 2000). Nock vd. 
(2008), duygusal tepkisellik kavramını üç boyut üzerinden incelemişlerdir. Bireyin duygusal tepkilerinin hangi durumlarda ortaya çıkacağl, duygusal tepkiselliğin duygusal hassasiyet boyutunu; verdiği tepkilerin kuvveti duygusal yoğunluğu; kişinin tepkiyi ne kadar sürdürdüğü ise duygusal süreklilik boyutunu ortaya koymaktadır. Duygusal tepkisellik duygu deneyiminin yoğun yaşanması olarak ele alındığında yalnızca olumsuz duygusal deneyimleri değil olumlu duygusal deneyimleri de kapsar (Spinrad vd., 2004). Duygusal tepkiselliğin yoğunluğu açısından bakıldığında, olumsuz duygu uyandıran yaşam olaylarına verilen tepkilerin olumlu duygu uyandıran tepkilerden daha yoğun olduğu tespit edilmiștir (Wheeler vd., 1993). İlgili alanyazında duygusal tepkisellik ile bireyin duygu düzenleme becerileri arasındaki ilişkiyi ortaya koyan çalışmalar mevcuttur (Retz vd., 2012). Cook vd. (2017) bireyin uyum bozucu deneyimlerinde duygularını bașarılı bir șekilde düzenlenmesinin göstergelerinden birinin duygusal tepkisellik olduğunu belirtmişlerdir. Shapero vd. (2016) yüksek seviyedeki duygusal tepkiselliğin birey için uyum bozucu sonuçlarla ilişkili olabileceğini ortaya koymuşlardır. Yüksek düzeyde duygusal tepkisellik yaşayan bireylerin tipik olarak stresli koşullara artan düzeyde olumsuz etki ile tepki verdikleri ve bu olaylarla ilgili uyumsuz değerlendirmelere sahip oldukları belirtilmektedir (Bylsma vd., 2015; Lee ve Woodruff-Borden, 2018). Bilişsel duygu düzenleme perspektifinden ele alındığında, duygu düzenlemede güçlük yaşayan bireylerin uğraşlarına rağmen istenmeyen duygular göstermeye devam etme eğiliminde oldukları görülmüştür (Kring ve Werner 2004). Psikopatoloji ile ilişkisi açısından duygusal tepkiselliğin derecesinin bireyin duygularını kendi kendine düzenleme becerisi ile ilişkili olduğu öne sürülmektedir (Gratz ve Hoemer, 2002). Buna paralel olarak, duygusal tepkiselliğin ölçülmesinde bireyin duygusal uyarılma eşiği, duygunun deneyimlendiği yoğunluk ve duygunun süresi açısından farklılıklara sebep olabilmektedir (Rothbart ve Derryberry, 1981; Rothbart vd. 2011). Eisenberg vd. (1995) duygusal tepkisellik düzeyleri ile sosyal destek arasındaki ilişkiyi açıklarken, yüksek bir genel duygusal tepkiselliğe sahip bireylerin daha yüksek düzeyde olumsuz duygular yaşamalarına ve daha az sosyal olmalarına işaret etmişlerdir.

Algılanan sosyal destek ve bilişsel duygu düzenlemenin bireylerin stresli yaşam olayları karşısında verdikleri olumsuz duygusal tepkileri açıklamadaki rolü araştırmanın temellendirilmesinde önemli bir rol oynamıştır. Yürütülen araştırma, duygusal tepkiselliğin tanımlanan alt boyutlarına ilişkin açıklayıcı faktörlerin belirlenmesi ve tartışma kısmında ele alınan alanyazın bulgularına ilaveten etkileşim halinde olan bilişsel duygu düzenleme ve algılanan sosyal destek türlerinin uyumlu duygusal tepkilerle ilişkilendirilmesi açısından önem kazanmaktadır. Duygu düzenleme ve bireyin algıladığı sosyal destek türlerinin olumsuz yaşantılar sonucu verilen tepkileri anlamak ve sözü edilen yaşamsal stresörlerle nasıl başa çıkıldığını ortaya ortaya koyabilmek hususunda önemli olduğu düşünülmektedir. İlişkili iki kavram olan bilişsel 
duygu düzenleme ile başa çıkmanın bilişsel düzeyi arasındaki ayrımı belirginleştirmek mevcut araştırmanın kapsamını ortaya koyabilmek adına önemlidir. Lazarus ve Folkman (1984) başa çıkmayı kişinin kaynaklarını zorlayan veya aşan belirli dış ve iç talepleri yönetmek için sürekli değişen bilişsel ve davranışsal çaba olarak tanımlamışlardır. Stresle başa çıkma sürecinde duyguları yönetme ve düzenlemeye yönelik yaklaşımlar daha çok duygu odaklı başa çıkma başlığı altında incelenmektedir. Problem odaklı başa çıkma ise, problemi çözmeye dayanmakta ve stresin kaynağına yönelik davranışsal ve bilişsel değişiklikler yaratma çabası devreye girmektedir. Başa çıkma stratejileri arasında duygu odaklı veya davranışsal etmenler mevcutken, bilişsel duygu düzenlemede bu etmenlerin mevcut olmadığı belirtilmektedir (Garnefski ve Kraaij, 2007). Hem duygusal hem de duygusal olmayan hedeflere yönelik çabaları içeren başa çıkmanın aksine, duygu düzenlemenin özellikle duygusal deneyimi değiștirmeyi hedefleyen süreçleri barındırdığı görülmektedir. Ayrıca, başa çıkmanın aksine, duygu düzenlemenin, stres bağlamı dışında bile hem olumlu hem de olumsuz duyguyu düzenleyen ve kasıtlı ve kasıtsız tepkileri içeren sürekli işleyen bir sistem olarak kavramsallaştırılabileceği belirtilmektedir (Marroquin vd., 2017). Mevcut çalışmada, bilişsel duygu düzenlemenin dokuz bileșeni ele alınmıştır. Kabul kişinin durumlara, olaylara ve duygularına dair kabul etme veya vazgeçme pozisyonunun ne derece benimsediğini ifade etmektedir. Carver vd. (1989), kabul alt boyutu için bireyin duyguyu işlemlerken koşulların uygun olmaması durumunda başa çıkamayacağını kabul etmesi şeklinde bir bakış açısı getirmiştir. Olumlu yeniden odaklanma olumsuz yaşam olayları üzerine düşünmek yerine olumlu çağrışımları olan ve görece mutlu, hoş düşüncelere odaklanmayı esas almaktadır. Plana yeniden odaklanma deneyimler ve duygularla başa çıkarken yararlanılabilecek iyi ve işlevsel alternatifleri belirlemeyi ifade etmektedir. Olumlu yeniden gözden geçirme kişisel gelişim çerçevesinde yaşananlara olumlu bir yükleme yapma eğiliminde olmayı ve yaşanan olayın birey için kazanımlarını ortaya koymayı belirtmektedir. Bakış açısına yerleştirme kişinin yaşadığı olayı diğer yaşam olaylarıyla kıyaslayıp algısal bir hafifleme yaşaması şeklinde ifade edilebilir. Kendini suçlama kişinin yaşadığı olaylara yönelik kendini suçlayıcı düşünme eğilimini ifade eder. Düşünceye odaklanma olumsuz olayların kişide yarattığı duygu ve düşüncelere tekrarlayıcı ve yoğun bir biçimde odaklanmasıdır. Yıkım, felaketleştirme olarak da isimlendirilebileceği gibi yaşanan olayın kişide yarattığı olumsuz çağrıșımları ön plana çlkaracak düşüncelerin olması şeklinde açıklanabilir. Bilişsel duygu düzenlemenin son bileşeni olan başkalarını suçlama, kişinin olumsuz deneyimlere dair yüklemeleri bir başkasına yapması olarak ifade edilebilir. Duygu düzenlemede kullanılan stratejilerin uyum derecesi bağlama uygunluk ve zamanlama gibi kriterler değerlendirilerek saptanabilir (Bonanno vd., 2004). Ayrıca kullanılan duygu düzenleme stratejilerinin birey için uyum derecesinin olumlu fizyolojik çıktılarla ilişkili olabileceği ortaya konmuştur (Appleton vd., 2013). Bilişsel duygu düzenlemenin sıralanan alt boyutlarından kabul etme, olumlu yeniden odaklanma, plana yeniden odaklanma ve bakış açısına yerleştirme kişi için 
daha işlevsel stratejiler içerisinde ele alınmaktadır. İşlevsel olmayan stratejiler arasında ise; kendini suçlama, düşünceye odaklanma (ruminasyon), yıkım ve başkalarını suçlama yer almaktadır (Garnefski, Kraaij ve Spinhoven, 2002; Gross ve John, 2013). Gross (1998) işlevsel sayılabilecek stratejilerin bilişsel davranışçı terapiler ile çalışırken bireylerin iyi oluşlarına katkıda bulunmasına ek bir biçimde anksiyete bozukluklarına karşı koruyucu bir etmen olabileceğini vurgulamıştır. Aynı çalışmada, bilişsel duygu düzenleme stratejileri ile duygusal problemler arasındaki ilişkilere bakıldığında kendini suçlama ve yıkım stratejilerinin bireyin olumsuz duygulanımı ile ilişkilenen güçlü değişkenler arasında olduğunu saptamışlardır.

Shapero vd. (2016) stres verici yaşantılar sonucu artan olumsuz değerlendirmeler ve bu değerlendirmelerle ilişkili olarak baş etmede güçlük yaşamanın yüksek duygusal tepkisellikle ilişkili olabileceğini öne sürmüşlerdir. Bir başka açıdan, Tampon Etki Modeline göre, bireylerin algıladıkları sosyal destek düzeyi stresli yaşam olaylarıyla başa çıkarken koruyucu bir faktör olabilmektedir (Cohen ve Wills, 1985). Stresle başa çlkma perspektifinden bakılınca, bilişsel duygu düzenleme kavramı, bireylerin zorlayıcı yaşam deneyimlerinden sonra tepkilerini yönetebilmeleri için duygularını bilişler aracıllğıyla kontrol etmek için benimsedikleri bir yöntem olarak ele alınabilir (Campbell-Sills ve Barlow, 2007; Garnefski vd., 2001). Algılanan sosyal desteğin uyumlu stres tepkileri üretebilmek gibi işlevlerinden ötürü ruh sağlığını etkileyen unsurlardan biri olduğuna dair birçok çalışma bulunmaktadır (Bolger ve Amarel, 2007; Bolger, Zuckerman ve Kessler, 2000). Duygu düzenlemenin olumsuz duyguların bireyin bilişsel değerlendirmelerini ve duygulara verilen tepkileri değiştirme etkisi göz önünde bulundurulduğunda, uyumlu stratejilerin kullanılmasının öznel iyi oluşa katkı sunabileceği düşünülmektedir. Araştırmanın temel motivasyonu üniversite öğrencilerinin algıladıkları sosyal desteğin ve kullandıkları bilişsel duygu düzenleme stratejilerinin duygusal tepkisellik düzeylerini nasıl etkilediğini ortaya koyarak alanyazına katkı sağlamaktır. Yürütülen araştırmada yanıt aranan sorular şu şekilde sıralanabilir:

1. Üniversite öğrencilerinde algllanan sosyal destek, bilişsel duygu düzenleme ve duygusal tepkisellik değişkenlerinin alt boyutları arasında anlamlı bir ilişki var midir?

2. Üniversite öğrencilerinde algllanan sosyal destek, bilișsel duygu düzenleme ve duygusal tepkisellik alt boyutları arasında cinsiyetlere göre bir farklılaşma var midir?

3. Algılanan sosyal destek alt boyutları (aile, arkadaş ve özel bir kişi) duygusal tepkisellik alt boyutlarını (hassasiyet, tepkisellik ve dayanıklılık) yordamakta midir? 
4. Bilişsel duygu düzenlemenin alt boyutları (kendini suçlama, kabul etme, düşünceye odaklanma, olumlu yeniden odaklanma, plana yeniden odaklanma, olumlu yeniden gözden geçirme, bakış açısına yerleştirme, yıkım ve diğerlerini suçlama) duygusal tepkiselliğin alt boyutlarını (hassasiyet, tepkisellik ve dayanıklılık) yordamakta mıdır?

\section{YÖNTEM}

\section{Araştırmanın Modeli}

Üniversite öğrencilerinin duygusal tepkisellik seviyeleri ile algılanan sosyal destek ve bilişsel duygu düzenleme becerileri arasındaki ilişkinin incelendiği bu araştırmada nicel tarama yöntemlerinden biri olan ilişkisel tarama modeli kullanılmıştır. İlişkisel tarama modeli, iki veya daha fazla değişken arasında birlikte değişim olup olmadığını ve değişimin derecesini belirlemeyi amaçlayan araştırma modelidir (Karasar, 2005).

\section{Çalıșma Grubu}

Araştırma örneklemi üniversite öğrencilerinden oluşmaktadır. Araştırmanın çalışma grubu Ankara, Diyarbakır, Eskişehir, Hatay, İstanbul, İzmir ve Trabzon illerinde öğrenim görmekte olan 400 üniversite öğrencisinden oluşmaktadır. Katılımcıların \%65.5'i $(n=262)$ kadın, \%34.5.1'i $(n=138)$ erkektir. Örneklemin \%65'i $(n=260)$ 18-21, \%29.8'i $(n=119)$ 22-25, \%5.3'ü ( $n=21) 26$ yaş ve üzeridir. Araştırmaya katılan üniversite öğrencilerinin \%2'si $(n=8)$ hazırlık sınıfı, \%23.3'ü ( $n=93)$ birinci sınıf, \%39.3'ü ( $n=157)$ ikinci sınıf, \%7.5’i ( $n=30)$ üçüncü sınıf, \%19.8'i $(n=79)$ dördüncü sınıf, \%4.5'i $(n=18)$ beşinci sınıf ve \%3.8'i $(n=15)$ altıncı sınıf öğrencileridir.

\section{Veri Toplama Araçları}

Demografik Bilgi Formu. Araştırmacılar tarafından hazırlanan Demografik Bilgi Formu, araştırmaya katılan üniversite öğrencilerinin cinsiyet, yaș, okudukları bölüm ve üniversite sınıf düzeyi gibi özelliklerini belirlemek amacıyla uygulanmıştır.

Çok Boyutlu Algılanan Sosyal Destek Ölçeği. Çok Boyutlu Algılanan Sosyal Destek Ölçeği, 1988 yılında Zimet vd. tarafından algılanan sosyal desteği aile, arkadaş ve özel bir insan düzeyinde değerlendirme amacıyla geliştirilmiştir. Toplamda 12 maddeden oluşan bu ölçek 7'li Likert tipinde (1=kesinlikle hayır, 7=kesinlikte evet) ve öz bildirime dayalı bir ölçektir. Bu ölçeğin Türkçe geçerlilik ve güvenirlik çalışması Eker, Arkar ve Yalnız (2001) tarafından gerçekleştirilmiş ve yapılan faktör analizleri sonucunda üç alt boyut (aile, arkadaş ve özel bir kişi) belirlenmiștir. Üç alt boyutun toplam varyansın \%75'ini açıkladığı bulunmuştur. Ölçeğin Türkçe formunun Cronbach alfa güvenirlik katsayısı .89 olarak bulunmuş olup alt boyutlarının iç tutarlılık 
katsayıları .95 ile .80 arasında değişiklik göstermektedir. Yapılan güvenirlik analizleri sonucunda araştırmada kullanılan Çok Boyutlu Algılanan Sosyal Destek Ölçeğinin iç tutarlılık güvenirlik katsayısı .87 olarak bulunmuștur.

Bilişsel Duygu Düzenleme ölçeği. Duygu düzenleme fizyolojik, sosyal ve davranışsal süreçlerin yanı sıra bilinçli ve bilinçsiz süreçleri de ölçmek amacıyla Garnefski, Kraaij ve Spinhoven (2001) tarafından geliştirilmiştir. Ölçeğin Türkçe uyarlamasını içeren geçerlik ve güvenirlik çalışması Onat ve Otrar (2010) tarafından yapılmıştır. 36 maddeden oluşan bu ölçek 5'li Likert tipinde (1=hiç uygun değil, 5= tamamıyla uygun) ve öz bildirime dayalıdır. Ölçek "kendini suçlama", "kabul etme", "düşünceye odaklanma”, "olumlu yeniden odaklanma", "plana yeniden odaklanma", "olumlu yeniden gözden geçirme", "bakış açısına yerleştirme", "yıkım”, "diğerlerini suçlama" olmak üzere 9 alt boyuttan oluşmaktadır. Ölçeğin genel Cronbach alfa iç tutarlılık katsayısı .78'tir. Alt boyutların iç tutarlılık katsayıları ise .51 ile .71 arasında değişmektedir. Ölçeklerin araştırma kapsamındaki güvenirlik analizleri sonucu Bilişsel Duygu Düzenleme Ölçeğinin 89 güvenirlik iç tutarlılık katsayısına sahip olduğu görülmüştür.

Duygusal Tepkisellik Ölçeği. İnsanların sosyal yaşam içerisinde yaşadığı duygular ve bu duyguların yoğunluğu, bu yoğunluk sonucu ortaya çıkan duygusal tepkiselliği ölçmek amacı ile Mathew vd. (2008) tarafından geliştirilen bu ölçek, 17 maddeden oluşan 4'lü Likert tipinde (1=hiç katılmıyorum, 2=katılmıyorum, 3=katılıyorum, 4= tamamen katılıyorum) öz bildirime dayalı bir ölçektir. Ölçeğin Türkçe geçerlik ve güvenirlik çalışması Seçer, Halmatov ve Gençdoğan (2013) tarafından yapılmıştır. Ölçek üç faktörden oluşmaktadır. Bu faktörler "hassasiyet", "duygusal tepkisellik" ve "psikolojik dayanıklılık" faktörleridir. Ölçeğin Türkçe formunun toplam Cronbach alfa iç tutarlılık katsayısı .91 bulunmuştur. Hassasiyet alt boyutunun iç tutarlılık katsayısı .86, tepkisellik alt boyutunun iç tutarlılık katsayısı .76 ve dayanıklılık alt boyutunun iç tutarlılık katsayısı .81 değerlerinde bulunmuştur. Çalışmada ölçeğin güvenirlik iç tutarlılık katsayısı .90 olarak bulunmuștur.

\section{Veri Toplama Süreci}

Çalışmada, katılımcılara bilgilendirilmiş onam formu aracılığıyla bilgi verilip izinleri alınmıştır. Katılımcılar çalışmaya gönüllülük esasıyla katılmıştır. Araştırmada kullanılan ölçekler Google Formlar aracılığıyla elektronik ortamda düzenlenmiş olup veriler Kasım-Aralık 2021 ayları arasında çevrimiçi olarak elde edilmiştir. Katılımcıların ölçekleri tamamlama süresi ortalama 20-25 dakika sürmüştür. Toplanan verilen IBM SPSS 23 İstatistik Programı ile analiz edilmiștir

\section{Verilerin Analizi}

Betimsel veriler analiz edilirken ortalama ve standart sapma değerlerinden yararlanılmıştır. Araştırmanın değişkenleri ile ilgili normallik varsayımı çarpıklık ve basıklık değerleri test edilerek incelenmiştir. Basıklık ve çarpıklık değerlerinin +1.5 ve -1.5 arasında 
olması verilerin normal dağılımını göstermektedir. (Tabachnick ve Fidell, 2013). Basıklık ve çarpıklık değerlerine bakıldığında algılanan sosyal destek değişkeninin -.41 ve -.30; bilişsel duygu düzenleme değişkeninin .32 ile .1.29; duygusal tepkiselliğin .10 ile -.52 değerlerinde olduğu görülmüştür. Yapılan analizler verilerin normal dağılım gösterdiğini ortaya koymaktadır (Tablo 1).

\section{Etik Onay}

Araştırmaya başlamadan önce Dicle Üniversitesi Sosyal ve Beșeri Bilimler Etik Kurulu Bașkanlığı tarafından (02/11/2021 tarih ve karar sayısı: 181076) değerlendirilmiș olup çalıșma için gerekli izin alınmıştır. Bilgilendirilmiş onam formu aracılığıyla katılımcılar çalışma hakkında bilgilendirilmiș, araştırmaya katılırken gizliliklerini ifşa edecek herhangi bir bilgi alınmamıştır.

\section{BULGULAR}

Üniversite öğrencilerinin duygusal tepkisellik düzeylerini değerlendirmek için Çok Boyutlu Algılanan Sosyal Destek Ölçeği ve Bilişsel Duygu Düzenleme ölçeğinden elde edilen toplam puanlara ait ortalama ile Duygusal Tepkisellik Ölçeğinin ortalama, standart sapma, basıklık ve çarpıklık değerleri incelenmiştir. Yapılan analize ilişkin bulgulara Tablo 1'de yer verilmiştir.

\section{Tablo 1}

Algılanan sosyal destek, bilişsel duygu düzenleme ve duygusal tepkisellik puanlarına ilişskin betimsel istatistikler ve basıklık-çarpıklık değerleri

\begin{tabular}{lccccc}
\hline Değișkenler & $\mathbf{N}$ & $\overline{\mathbf{x}}$ & $\mathbf{S s}$ & Çarpıklık & Basıklık \\
\hline Algllanan Sosyal Destek & 399 & 59.10 & 15.31 & -.41 & -.30 \\
Bilișsel Duygu Düzenleme & 399 & 118.66 & 15.08 & .32 & 1.29 \\
Duygusal Tepkisellik & 399 & 41.58 & 10.66 & .10 & -.52 \\
\hline
\end{tabular}

Üniversite öğrencilerinde cinsiyet değişkenine göre duygusal tepkisellik, algılanan sosyal destek ve bilişsel duygu düzenleme puanlarının birbirinden anlamlı şekilde farklılaşıp farklılaşmadığını belirlemek için Bağımsız Örneklemler t testi analizi yapılmıştır. Elde edilen bulgular Tablo 2'de sunulmuştur. 
Tablo 2

Araştırma değişkenlerine ait alt boyutların cinsiyet açısından karşılaştırılmasına Illişkin t-testi Bulguları

\begin{tabular}{|c|c|c|c|c|c|c|c|}
\hline \multirow{2}{*}{ Değişkenler } & \multirow{2}{*}{ Alt Boyutlar } & \multicolumn{2}{|c|}{ Erkek } & \multicolumn{2}{|c|}{ Kadın } & \multirow{2}{*}{$t$} & \multirow{2}{*}{$p$} \\
\hline & & $\overline{\mathbf{x}}$ & Ss & $\overline{\mathbf{x}}$ & Ss & & \\
\hline \multirow{3}{*}{ Algılanan Sosyal Destek } & Aile & 5.19 & 1.44 & 5.40 & 1.63 & .31 & .06 \\
\hline & Arkadaș & 5.23 & 1.64 & 5.44 & 1.46 & .35 & .08 \\
\hline & Özel Bir Kiși & 4.03 & 2.23 & 4.08 & 2.33 & .20 & .57 \\
\hline \multirow{9}{*}{ Bilişsel Duygu Düzenleme } & Kabul Etme & 3.38 & .70 & 3.45 & .75 & -.60 & .53 \\
\hline & Plana Yeniden Odaklanma & 4.00 & .71 & 3.84 & .88 & 1.98 & .00 \\
\hline & Olumlu Yeniden Odaklanma & 2.85 & .89 & 2.73 & 1.00 & 1.16 & .16 \\
\hline & Olumlu Yeniden Gözden Geçirme & 3.68 & .85 & 3.59 & .97 & .91 & .12 \\
\hline & Bakış Açısına Yerleştirme & 3.26 & .83 & 3.45 & .95 & -2.06 & .03 \\
\hline & Kendini Suçlama & 3.41 & .73 & 3.40 & .79 & .20 & .37 \\
\hline & Diğerlerini Suçlama & 2.59 & .80 & 2.56 & .84 & .43 & .38 \\
\hline & Yıkım & 2.60 & .85 & 2.80 & .98 & -2.14 & .05 \\
\hline & Düşünceye Odaklanma & 3.68 & .80 & 3.96 & .78 & -3.38 & .74 \\
\hline \multirow{3}{*}{ Duygusal Tepkisellik } & Hassasiyet & 2.44 & .75 & 1.98 & 82 & -5.46 & .37 \\
\hline & Tepkisellik & 2.77 & .61 & 2.60 & .71 & -2.52 & .03 \\
\hline & Dayanıklılık & 2.67 & .71 & 2.32 & .66 & -4.71 & .32 \\
\hline
\end{tabular}

Tablo 2'deki bulgulara göre, bilişsel duygu düzenlemenin plana tekrar odaklanma alt boyutundan alınan puanlara göre, erkeklerin plana tekrar odaklanma düzeylerinin $($ Ort $=4.00, S S=$ .71) kadınların plana tekrar odaklanma düzeylerinden (Ort=3.84, SS= .88) anlamlı şekilde yüksek $\left(t_{(334)}=1.98, p<.001\right)$ olduğu belirlenmiştir. Kadınların bakış açısına yerleștirme düzeyleri (Ort= $3.45, S S=.95)$ ise erkeklerin bakış açısına yerleştirme düzeylerinden (Ort=3.26, $S S=.83$ ) anlamlı olarak yüksek bulunmuştur $\left(t_{(313)}=-2.06, p<.05\right)$. Kadınların yıkım düzeyleri (Ort= 2.80, $S S=.85$ ) ile erkeklerin yıkım düzeyleri (Ort=2.60, $S S=.85)$ arasındaki fark açısından, kadınların anlamlı olarak daha yüksek düzeyde olduğu bulunmuștur. $\left(t_{(315)}=-2.14, p=.05\right)$. Duygusal tepkisellik değişkeninin tepkisellik alt boyutundan alınan puanlara göre, erkeklerin tepkisellik düzeylerinin $(O r t=2.77, S S=.61)$ kadınların tepkisellik düzeylerinden (Ort= 2.61, SS= .71) anlaml olarak yüksek olduğu görülmüştür $\left(t_{(315)}=-2.52, p=.05\right)$. Yapılan analiz sonucu algılanan sosyal desteğin alt boyutlarından alınan puanların cinsiyetler arasında farklılaşmadığı görülmüştür. Bilişsel duygu düzenlemenin kabul etme, olumlu yeniden odaklanma, olumlu yeniden gözden geçirme, kendini suçlama ve diğerlerini suçlama; duygusal tepkiselliğin ise hassasiyet ve dayanıklılık alt boyutlarından alınan puanların cinsiyete göre farklılașmadığı sonucuna ulașılmıștır ( $p>.05)$.

Katılımcıların duygusal tepkisellik, algılanan sosyal destek ve bilişsel duygu düzenlemenin alt boyutlarından aldıkları puanlarını karşılaştırmak birbirleriyle ilişkilerini incelemek adına Pearson Momentler Çarpımı Korelasyon analizi uygulanmış ve elde edilen bulgular Tablo 3'te sunulmuştur. 
Tablo 3

Kullanılan ölçme araçlarının alt boyutlar arası korelasyon katsayıları

\begin{tabular}{|c|c|c|c|c|c|c|c|c|c|c|c|c|c|c|c|}
\hline Alt Boyutlar & 1 & 2 & 3 & 4 & 5 & 6 & 7 & 8 & 9 & 10 & 11 & 12 & 13 & 14 & 15 \\
\hline 1. Aile & 1 & & & & & & & & & & & & & & \\
\hline 2. Arkadaş & $.35^{* *}$ & 1 & & & & & & & & & & & & & \\
\hline 3. Özel bir insan & $.15^{* *}$ & $.24^{* *}$ & 1 & & & & & & & & & & & & \\
\hline 4.Kabul etme & .01 & .06 & .02 & 1 & & & & & & & & & & & \\
\hline 5. Plana tekrar odaklanma & $.27^{* *}$ & $.19^{* *}$ & .06 & $.27^{* *}$ & 1 & & & & & & & & & & \\
\hline 6. Pozitif tekrar odaklanma & $.24^{* *}$ & $.21^{* *}$ & $.11^{*}$ & $.31^{* *}$ & $.31^{* *}$ & 1 & & & & & & & & & \\
\hline 7. Bakış açısına yerleştirme & $.27^{* *}$ & $.10^{* *}$ & .09 & $.37^{* *}$ & $.37^{* *}$ & $.45^{* *}$ & 1 & & & & & & & & \\
\hline 8. Pozitif yeniden gözden geçirme & $.23^{* *}$ & $.17^{* *}$ & .09 & $.63^{* *}$ & $.63^{* *}$ & $.56^{* *}$ & $.57^{* *}$ & 1 & & & & & & & \\
\hline 9. Kendini suçlama & $-.10^{*}$ & -.01 & -.06 & -.01 & -.10 & $-.17^{* *}$ & .07 & -.10 & 1 & & & & & & \\
\hline 10. Yıkım & $-.14^{*}$ & $-.11^{*}$ & -.05 & $-.29^{* *}$ & $-.29 * *$ & $-.17^{* *}$ & -.09 & $-.37^{* *}$ & $.40^{* *}$ & 1 & & & & & \\
\hline 11.Diğerlerini suçlama & -.12 & -.07 & .02 & $-.10^{* *}$ & $-.10^{*}$ & .06 & .01 & .05 & $.10^{*}$ & $-.45^{* *}$ & 1 & & & & \\
\hline 12.Düşünceye odaklanma & .10 & $.10^{*}$ & .05 & $.23^{* *}$ & $.22^{* *}$ & -.07 & .06 & $.16^{* *}$ & $.38^{* *}$ & $.15^{* *}$ & .05 & 1 & & & \\
\hline 13.Hassasiyet & .00 & -.06 & .06 & .02 & $.13^{*}$ & $.26^{* *}$ & .03 & $.16^{* *}$ & $-.18^{* *}$ & $-.16^{* *}$ & .00 & $-.27^{* *}$ & 1 & & \\
\hline 14.Tepkisellik & $.21^{* *}$ & .08 & $.12^{*}$ & .02 & $.29 * *$ & $.38^{* *}$ & $.15^{* *}$ & $.38^{* *}$ & $-.26^{* *}$ & $-.33^{* *}$ & $-.16^{* *}$ & $-.19 * *$ & $.51^{* *}$ & 1 & \\
\hline 15.Dayanıklılık & $.11^{*}$ & .03 & .04 & .08 & $.19^{* *}$ & $.30^{* *}$ & .10 & $.25^{* *}$ & $-.17^{* *}$ & $-.20^{* *}$ & -.06 & $-.22^{* *}$ & $-.73^{* *}$ & $-.64^{* *}$ & 1 \\
\hline
\end{tabular}

${ }^{*} p<.05,{ }^{* *} p<.01$ 
Tablo 3’te görüldüğü gibi bilişsel duygu düzenleme değişkeninin algılanan sosyal destek değişkeniyle ilişkisi incelendiğinde, "plana tekrar odaklanma" algılanan sosyal desteğin "aile" $(r=.27, p<.001)$ ve "arkadaş" $(r=.19, p<.001)$ alt boyutları ile pozitif yönde bir ilișki saptanmıştır. Bilişsel duygu düzenlemenin "pozitif tekrar odaklanma" alt boyutu ile algılanan sosyal desteğin "aile" ( $r=.24, p<.001)$, "arkadaş" ( $r=.21, p<.001)$ ve "özel bir insan" ( $r=.10$, $p<.05$ ) alt boyutları arasında pozitif yönlü bir ilişki bulunmuştur. Bilişsel duygu düzenlemenin "bakış açısına yerleştirme" alt boyutu ile algılanan sosyal desteğin "aile" ( $r=.265, p<.001)$, "arkadaş" ( $r=.10, p<.001)$ alt boyutları arasında pozitif bir ilişki belirlenmiştir. Bilişsel duygu düzenlemenin "pozitif yeniden gözden geçirme" alt boyutu ile algılanan sosyal desteğin "aile" ( $r=.23, p<.001)$ ve "arkadaş" $(r=.17, p<.001)$ alt boyutları arasında pozitif bir ilişki bulunmuştur. Bilişsel duygu düzenlemenin "kendini suçlama" alt boyutu ile algılanan sosyal desteğin "aile" alt boyutu arasında negatif yönlü bir ilişki belirlenmiștir $(r=-.10, p<.05)$. Bilişsel duygu düzenlemenin "yıkım" alt boyutu ile algılanan sosyal desteğin "aile" $(r=-.13, p<.001)$ ve "arkadaş" ( $r=-.11, p<.05)$ alt boyutları arasında negatif bir ilişki bulunmuştur. Bilişsel duygu düzenlemenin "diğerlerini suçlama" alt boyutu ile "aile" $(r=-.12, p<.05)$ arasında negatif yönlü bir ilişki belirlenmiștir. Bilișsel duygu düzenlemenin "düşünceye odaklanma" alt boyutu ile algılanan sosyal desteğin "arkadaş" alt boyutu ile $(r=.10, p<.05)$ pozitif ve düşük seviyede bir ilişki bulunmuştur.

Algılanan sosyal destek değişkeninin alt boyutları ile duygusal tepkisellik değişkeninin alt boyutları arasındaki ilişki incelendiğinde, duygusal tepkiselliğin "tepkisellik" alt boyutu ile algılanan sosyal desteğin "aile" ( $r=.21, p<.001)$ ve "özel bir insan" $(r=.12, p<.05)$ alt boyutları arasında bir ilişki bulunmuştur. Duygusal tepkiselliğin "dayanıklılık" alt boyutu ile algılanan sosyal desteğin "aile" alt boyutu arasında pozitif bir ilişki bulunmuştur $(r=.11, p<.05)$. Duygusal tepkiselliğin "hassasiyet" alt boyutu ile algılanan sosyal desteğin alt boyutları arasında anlamlı bir ilişki bulunamamıştır.

Bilişsel duygu düzenlemenin alt boyutları ile duygusal tepkiselliğin alt boyutları arasındaki ilişki incelendiğinde, bilişsel duygu düzenlemenin "kabul etme" alt boyutu ile duygusal tepkiselliğin alt boyutları arasında anlamlı bir ilişkiye rastlanmamıştır. Bilişsel duygu düzenlemenin "plana tekrar odaklanma" alt boyutu ile duygusal tepkiselliğin "hassasiyet" ( $r=.13$, $p<.05)$, "tepkisellik" ( $r=.29, p<.001)$ ve "dayanıklılı" ( $r=.19, p<.001)$ alt boyutları arasında pozitif bir ilişki bulunmuștur. Bilișsel duygu düzenlemenin "pozitif tekrar odaklanma" alt boyutu ile duygusal tepkiselliğin "hassasiyet" $(r=.26, \quad p<.001)$, "tepkisellik" $(r=.37, \quad p<.001)$ ve "dayanıklılık" ( $r=.30, p<.001)$ alt boyutları arasında pozitif bir ilişkiye rastlanmıştır. Bilişsel duygu düzenlemenin "bakış açısına yerleştirme" alt boyutu ile duygusal tepkiselliğin "tepkisellik" alt boyutu arasında pozitif bir ilişki saptanmıştır $(r=.15, p<.001)$. Bilişsel duygu düzenlemenin 
"pozitif yeniden gözden geçirme" alt boyutu ile duygusal tepkiselliğin "hassasiyet" $(r=.16, p<.001)$, "tepkisellik" ( $r=.38, p<.001)$ ve "dayanıklılık" $(r=.245, p<.001)$ alt boyutları arasında pozitif bir ilişki bulunmuştur. Bilişsel duygu düzenlemenin "kendini suçlama" alt boyutu ile duygusal tepkiselliğin "hassasiyet" ( $r=.-18, p<.001)$, "tepkisellik" $(r=-.26, p<.001)$ ve "dayanıklılık" $(r=-$ $.165, p<.001$ ) alt boyutları arasında negatif yönlü bir ilişkiye rastlanmıştır. Bilişsel duygu düzenlemenin "yıkım" alt boyutu ile duygusal tepkiselliğin "hassasiyet" $(r=-.16, p<.001)$, "tepkisellik" ( $r=-.33, p<.001)$ ve "dayanıklılı" $(r=-.20, p<.001)$ alt boyutları arasında negatif bir ilişski belirlenmiştir. Bilişsel duygu düzenlemenin "diğerlerini suçlama" alt boyutu ile duygusal tepkiselliğin "tepkisellik" alt boyutu arasında negatif yönlü bir ilişki bulunmuştur ( $r=-.155$, $p<.001)$. Bilişsel duygu düzenlemenin "düşünceye odaklanma” alt boyutu ile duygusal tepkiselliğin "hassasiyet" ( $r=-.27, p<.001)$, "tepkisellik" ( $r=-.19, p<.001)$ ve "dayanıklılı" ( $r=-.22$, $p<.001$ ) alt boyutları arasında negatif yönlü bir ilişki bulunmuştur.

Araştırmanın amaçlarından biri de duygusal tepkiselliğin alt boyutlarının yordanmasında algılanan sosyal destek ve bilişsel duygu düzenlemenin alt boyutlarının etkisini ortaya koymaktır. Pearson Momentler Çarpımı Korelasyon analizi sonucu duygusal tepkiselliğin hassasiyet alt boyutuyla ilişkili bulunan plana yeniden odaklanma, olumlu yeniden odaklanma, olumlu yeniden gözden geçirme, düşünceye odaklanma, kendini suçlama ve yıkımın; tepkiselik alt boyutuyla ilişkili bulunanan aile, bakış açısına yerleștirme, plana yeniden odaklanma, olumlu yeniden odaklanma, olumlu yeniden gözden geçirme, düşünceye odaklanma, kendini suçlama, diğerlerini suçlama ve yıkım; dayanıklılık alt boyutuyla ilişkili bulunan olumlu yeniden odaklanma, plana yeniden odaklanma, olumlu yeniden gözden geçirme, düşünceye odaklanma, kendini suçlama ve yıkım değişkenlerinin yordayıcı etkisini belirleyebilmek amacıyla çoklu doğrusal regresyon analizi yapılmıştır. Yapılan analiz sonucu yordayıcı etkisi saptanan değişkenler Tablo 4'te sunulmuştur.

\section{Tablo 4}

Duygusal Tepkisellik Ölçeği Alt Boyut Puanlarının Yordanması için Çoklu Doğrusal Regresyon Analizi Sonuçları

\begin{tabular}{|c|c|c|c|c|}
\hline & $\mathbf{R}^{2}$ & $F$ & Bağımsız Değișkenler & $\mathbf{t}$ \\
\hline \multirow{2}{*}{ Hassasiyet } & \multirow{2}{*}{.14} & \multirow{2}{*}{$13.00^{* * *}$} & Olumlu Yeniden Odaklanma & $3.25^{* * *}$ \\
\hline & & & Füșünceye Odaklanma & $-4.79 * * *$ \\
\hline \multirow{6}{*}{ Tepkisellik } & \multirow{6}{*}{.31} & \multirow{6}{*}{$17.07^{* * *}$} & Aile & $1.98^{*}$ \\
\hline & & & Plana Yeniden Odaklanma & $1.97^{*}$ \\
\hline & & & Bakıș Açısına Yerleștirme & $-2.68^{* *}$ \\
\hline & & & Olumlu Yeniden Odaklanma & $3.75^{* * *}$ \\
\hline & & & Olumlu Yeniden Gözden Geçirme & $3.51^{* * *}$ \\
\hline & & & Düşünceye Odaklanma & $-4.30^{* * *}$ \\
\hline \multirow{3}{*}{ Dayanıklılık } & \multirow{3}{*}{.17} & \multirow{3}{*}{$12.93^{* * *}$} & Plana Yeniden Odaklanma & $1.97^{*}$ \\
\hline & & & Olumlu Yeniden Odaklanma & $3.32^{* * *}$ \\
\hline & & & Düşünceye Odaklanma & $-4.44^{* * *}$ \\
\hline
\end{tabular}


${ }^{*} p<.05,{ }^{* *} p<.01,{ }^{* * *} p<.001$

Duygusal tepkiselliğin hassasiyet alt boyutunu yordama etkisi olan algllanan sosyal destek ve bilişsel duygu düzenleme alt boyutlarını belirlemek adına çoklu doğrusal regresyon analizi yapılmıştır. Elde edilen sonuçlara göre, olumlu yeniden odaklanma alt boyut puanının hassasiyete etkisi istatistiksel olarak anlamlı ve pozitif yönde olduğu tespit edilmiştir $\left(\mathrm{F}_{(5,393)}=13,10 ; p<0.001\right)$. Hassasiyet alt boyut puanının yordanmasında düşünceye odaklanma alt boyut puanının etkisi $\left(\mathrm{F}_{(5,393)}=-4.79 ; p<0.001\right)$ negatif yönde bir anlamlılı̆ga ișaret etmektedir. Hassasiyet alt boyutunun toplam puanının \%14'lük kısmının istatistiksel olarak anlamlı bulunan bilişsel duygu düzenleme stratejileriyle açıklandığı görülmüştür. Tabloda görüldüğü gibi, duygusal tepkiselliğin tepkisellik alt boyutunu yordayan bağımsız değisskenler incelendiğinde, algılanan sosyal desteğin aile alt boyutunun tepkiselliğe etkisi $\left(\mathrm{F}_{(10,388)}=1.98 ; p<0,05\right)$ pozitif yönde bir anlamlllı̆ga işaret etmektedir. Bilişsel duygu düzenlemenin plana yeniden odaklanma $\left(\mathrm{F}_{(10,388)}=1.97 ; p<0,05\right)$, olumlu yeniden odaklanma $(\mathrm{F}(10,388)=3.75 ; p<0,001)$ ve olumlu yeniden gözden geçirme $\left(\mathrm{F}_{(10,388)}=3.51 ; p<0,001\right)$ alt boyutlarının tepkiselliğin yordanmasında pozitif ve anlamlı bir etkisi olduğu bulunmuştur. Bakış açısına yerleştirme $\left(\mathrm{F}_{(10,388)}=-2.68 ; p<0,01\right)$ ve düşünceye odaklanma $\left(\mathrm{F}_{(10,388)}=-4.44 ; p<0,001\right)$ alt boyutlarının tepkiselliğe anlamlı ve negatif bir etkisinin olduğu görülmüştür. Plana yeniden odaklanma, olumlu yeniden odaklanma, olumlu yeniden gözden geçirme, bakış açısına yerleştirme ve düşünceye odaklanma alt boyutlarının tepkisellik alt boyut puanının açıklanmasında \%31'lik bir etkisi olduğu görülmüştür. Duygusal tepkiselliğin üçüncü ve son alt boyutu olan dayanıklılığın açıklanmasında plana yeniden odaklanma $\left(\mathrm{F}_{(6,392)}=1.97 ; p<0,05\right)$ ve olumlu yeniden odaklanma $\left(\mathrm{F}_{(6,392)}=3.32 ; p<0,001\right)$ alt boyutlarından alınan toplam puanların anlamlı ve pozitif etkisi olduğu bulunmuştur. Düşünceye odaklanma $\left(\mathrm{F}_{(6,392)}=-4.44 ; p<0,001\right)$ alt boyutunun dayanıklılığa etkisine bakıldığında anlamlı ve negatif yönde bir yordayıcılığı olduğu saptanmıştır. Dayanıklılık alt boyutundan alınan toplam puanların açıklanmasında sıralanan bilişsel duygu düzenleme değişkenlerinin \%17'lik bir katkısı olduğu görülmüştür.

\section{TARTIŞMA, SONUÇ VE ÖNERÍLER}

Üniversite öğrencilerinin algıladığı sosyal destek türlerinin kullandıkları bilişsel duygu düzenleme stratejileri ile ilişkisini ortaya koymak amacıyla yapılan analizler sonucu iki değişkenin alt boyutları arasında anlamlı ilişkiler olduğu görülmüștür. Algılanan sosyal desteğin aile alt boyutu ile ilişkili bulunan uyumlu bilişsel duygu düzenleme stratejileri; plana yeniden odaklanma, olumlu yeniden odaklanma, olumlu yeniden gözden geçirme, bakış açısına yerleștirme olarak bulunmuştur. Aile ile negatif yönlü ilişkisi bulunan uyumsuz stratejiler kendini suçlama, yıkım ve diğerlerini suçlamadır. Algılanan sosyal desteğin arkadaş alt boyutu ile ilişkili bulunan uyumlu bilişsel duygu düzenleme stratejileri arasında plana yeniden odaklanma, olumlu 
yeniden odaklanma, olumlu yeniden gözden geçirme, bakış açısına yerleştirme; uyumsuz stratejilerden ise yıkım bulunmaktadır. Bilişsel duygu düzenlemenin olumlu yeniden odaklanma alt boyutunun algılanan sosyal desteğin özel bir kiși alt boyutu ile ilişkili olduğu bulunmuştur. Yürüttüğümüz araştırma sonuçlarının alanyazında ilgili değişkenlerle yapılan çalışmalarla tutarlılık gösterdiği söylenebilir. Morris vd. (2007) tarafından yapılan bir çalışmada, çocukların aile ve akranlarından algıladıkları sosyal desteğin duygu düzenleme becerilerinin şekillenmesinde etkili olduğu görülmüştür. Pejičić vd.'nin (2018) algllanan sosyal destek ile bilişsel duygu düzenlemenin ilişkisini inceledikleri çalışmaları; algılanan sosyal desteğin aile, arkadaş ve özel bir insan alt boyutlarının bilişsel duygu düzenlemenin bakış açısına yerleștirme, olumlu yeniden odaklanma, olumlu yeniden gözden geçirme ve plana yeniden odaklanma alt boyutlarıyla pozitif ilişkili olduğunu göstermiştir. Aynı çalışmada aile, arkadaş ve özel bir kişi alt boyutlarının bilişsel duygu düzenlemenin yıkım alt boyutu ile negatif ilişkili olduğu saptanmıştır. Mevcut çalışmada aileden alınan sosyal desteğin yıkımla negatif ilişkili olduğu görülmüştür. Buna göre, aile veya arkadaşlıklardan algılanan sosyal destek düzeyi arttıkça, yıkım alt boyutundan alınan puanın azaldığı sonucuna ulaşılmıștır. Bireylerin stresli yaşantılar sonucu olabileceklere dair olumsuz çağrışımlar yapması ve felaketleştirme eğilimi yıkım alt boyutunu daha iyi açılamaktadır. Uyumsuz bilişsel duygu düzenleme stratejilerini kullanma ve benimseme hususunda bireylerin sosyal destek aramak yerine kendilerini sosyal etkileşimlerden uzaklaştırdıkları söylenebilir. Bununla birlikte, sosyal desteğin artmasının uyumlu bilişsel duygu düzenleme stratejilerini kullanma eğilimini artırdığı belirtilmektedir (Cai vd., 2017). Boylamsal bir çalışmada, duygu aralığı görece dar bireylerin daha düşük duygu düzenlemeye sahip oldukları ve yeni arkadaşlardan daha az sosyal destek aldıkları gösterilmiştir (Tamir vd., 2007).

Alanyazınla ve araştırma bulgularıyla paralel olarak bireyin uyumsuz ve işlevsel olmayan duygu düzenleme stratejilerini kullanmasında aile bașta olmak üzere diğer sosyal destek kaynaklarından algıladıkları sosyal desteğin önemi göze çarpmaktadır. Uyumlu bilişsel duygu düzenleme stratejileri ve algılanan sosyal destek ilişkisine bakıldığında; kişinin algıladığı sosyal destek düzeyinin pozitif yeniden gözden geçirme, olumlu yeniden odaklanma, bakış açısına yerleştirme alt boyutları ile pozitif; kendini suçlama ve diğerlerini suçlama alt boyutları ile ise negatif ilişkisi olduğu sonucuna ulaşılmıştır (Urano ve Ikeda, 2020). Bu sonuçların yanı sıra, algılanan sosyal desteğin yüksek olmasının uyumlu ve uyarlanabilir bilişsel duygu düzenleme stratejileri ile psikolojik sıkıntı değişkenleri arasındaki negatif ilişkiyi düzenleyici bir rolü olabileceğinin altı çizilmiştir. Zhou vd.'nin (2017) ergenlerle yürüttükleri bir çalışma, olumlu yeniden gözden geçirme alt boyutu ile sosyal destek seviyesi arasındaki pozitif ilişkiye işaret edilmiştir. Uyum sağlayan stratejiler (olumlu yeniden odaklanma, olumlu yeniden gözden geçirme vb.) uyumsuz stratejilere (yıkım, kendini suçlama vb.) kıyasla bağlamdan daha fazla etkilenmektedir (Aldao ve Nolen-Hoeksema, 2012). Bağlamın da etkisiyle algıladığı sosyal destek 
seviyesi yüksek bireylerin uyumsuz bilişsel duygu düzenleme stratejilerini çevrelerinden aldıkları geribildirimler neticesinde daha az kullandıkları düşünülmektedir.

Çalışmanın yanıtlamayı hedeflediği sorulardan biri; algılanan sosyal destek, bilişsel duygu düzenleme ve duygusal tepkisellik değişkenlerinin alt boyutlarından alınan puanların katılımcıların cinsiyetlerine göre farklılaşıp farklılaşmadı̆̆ıdır. Yapılan analiz sonucu bilişsel duygu düzenlemenin alt boyutlarından plana yeniden odaklanma, bakış açısına yerleştirme ve yıkım ile duygusal tepkiselliğin alt boyutlarından tepkisellikten alınan puanlar arasında cinsiyetler arası anlamlı farklılıklar saptanmıștır. Ayrıca duygusal tepkiselliğin alt boyutu olan tepkisellik düzeyinin erkeklerde kadınlara kıyasla daha yüksek olduğu bulunmuştur. Dolayısıyla duygusal tepkisellikteki cinsiyet farklılıkları açıklanırken, stresli olaylara tepki olarak kullanılan duygusal düzenleme stratejilerindeki potansiyel bir cinsiyet farklıllı̆ı göz önünde bulundurulmalıdır. Duygu düzenleme stratejileri üstüne yapılan epidemiyolojik çalışmalarda cinsiyetin depresyon ve anksiyete yaygınlığı ile ilgili en tutarlı yordayıcılardan biri olduğu bulunmuştur. Sobol vd. (2021) depresif belirtiler, bilişsel duygu düzenleme ve algılanan sosyal destek değişkenleri ile yürüttükleri çalışmada, sağlıklı ergen grubundaki bireyler arasında cinsiyetler arası bir fark saptamışlardır. Sağlıklı kız ergen grubunda arkadaş ve özel bir insan tarafından algılanan sosyal destek erkeklere kıyasla daha anlamlı bulunmuştur. Çalışmada erkeklerin plana yeniden odaklanma düzeyleri daha yüksekken kadınların ise bakış açısına yerleştirme ve yıkım düzeylerinin daha yüksek olduğu bulunmuştur. İlgili alanyazında ise, kadınların erkeklere kıyasla daha çok düşünceye odaklanma ve bakış açısına yerleştirme stratejilerini kullanırken, erkeklerin de başkalarını suçlama stratejilerini daha çok kullandığına dair bulgulara rastlanmaktadır (Sobol, Woźny ve Czubak-Paluch, 2021). Ayrıca yapılan farklı çalışmalarda, kadınların sorunlara yaklaşımda erkeklere kıyasla düşünceye odaklanma veya yıkım gibi daha az uyumlu stratejiler kullanma eğiliminde oldukları sonucuna ulaşılmıștır (Folkman, 2013; Garnefski vd., 2004). Maffei vd. (2015) tarafından yapılan bir çalışmada, kadınların rahatsız edici stresli koşullarına karşı daha hassas ve daha düşük dayanıklılıkta olduğu bulgusuna ulaşılmıştır. Zlomke ve Hahn (2010), kadınların erkeklerden daha fazla düşünceye odaklandıklarını ve bakış açısına yerleştirdiklerini; erkeklerin ise başkalarını suçlama stratejisini daha fazla kullandıklarını tespit etmişlerdir. Bu bulgular araştırma sonuçlarını destekler niteliktedir; mevcut çalışmada yıkım stratejisini kullanma kadınlarda daha yüksek bir oranda görülmüştür. Elde edilen sonuç üzerinde, kadınların toplumsal cinsiyet rollerinin etkisiyle yıkım ve düşünceye odaklanma gibi eylemsizlikle daha çok ilişkili stratejileri kullanma eğiliminde olabilecekleri düşünülmektedir.

Elde edilen sonuçlara göre, duygusal tepkisellik değişkeninin alt boyutlarından hassasiyet, tepkisellik ve dayanıklılığın yordanmasında algılanan sosyal destek ve bilişsel duygu 
düzenlemenin alt boyutlarının etkisi olduğu bulunmuştur. Bilişsel duygu düzenlemenin olumlu yeniden odaklanma ve düşünceye odaklanma alt boyutlarının hassasiyeti \%14'lük açıklayıcı etkisiyle yordadığı görülmüştür. Düşünceye odaklanma, duygusal tepkiselliğin alt boyutu olan hassasiyeti negatif bir şekilde yordamıştır. Tepkisellik alt boyutuna bakıldığında, algılanan sosyal desteğin aile; bilişsel duygu düzenlemenin plana yeniden odaklanma, bakış açısına yerleştirme, olumlu yeniden odaklanma, olumlu yeniden gözden geçirme ve düşünceye odaklanma alt boyutlarının \%31 oranında yordayıcı etkisi olduğu saptanmıştır. Elde edilen sonuçlara göre; bakış açısına yerleștirme ve düşünceye odaklanmanın negatif bir yordayıcı olduğu bulunmuştur. Duygusal tepkiselliğin alt boyutlarından dayanıklılığın yordanmasında bilişsel duygu düzenlemenin plana yeniden odaklanma, olumlu yeniden odaklanma ve düşünceye odaklanma alt boyutlarının \%17'lik açıklayıcı etkisi olduğu görülmüştür. Düşünceye odaklanma aynı hassasiyet ve tepkisellikte olduğu gibi dayanıklılığı negatif bir şekilde yordamıştır. Yurdakul ve Öner (2015), duygusal tepkiselliğin kavramsallaştırılmasında bireyin sosyal çevresi ile kurduğu etkileşim sonucu uyanan duyguları, bu duyguları nasıl karşılandığı ve nasıl tepki verildiğinin önemini vurgulamıştır. İlgili alanyazındaki bir çalışma, yüksek duygusal tepkiselliğin yüksek cerrahi kaygı ile sonuçlandığını göstermektedir (Aliche vd., 2019). Hastaların aile, arkadaşlar veya diğer kişilerden aldığı sosyal desteği algılama derecesinin de duygusal tepkisellik ile cerrahi kaygl ilişkisini etkilediği bulunmuştur. Ayrıca yüksek duygusal tepkiselliğin bireylerin aileden, arkadaştan veya diğer kişilerden aldığı sosyal destekten etkilendiği; sosyal destek düzeyi arttıkça cerrahi kaygının anlamlı olarak azaldığı görülmüştür. Yaş, cinsiyet ve çevresel koşullarının da etkisiyle bireyin elde ettiği sosyal desteğin kaynakları değişkenlik gösterebilmektedir. Mevcut araştırmanın bulgularına göre, duygusal tepkiselliğin tepkisellik alt boyutunda algllanan aile desteği yordayıcı bir değişken olarak bulunmuştur. Aile kaynaklı sosyal desteğin sabit doğası ve ihtiyaca yönelik olması nedeniyle aile desteğinin birey için daha ön planda olduğu belirtilmektedir (Sting vd., 2004). Rabinowitz vd. (2016) aile bağlılığı ile duygusal tepkiselliğin uyum bozucu yönlerinin negatif ilişkisine işaret etmiştir. Duygusal tepkiselliğin yanı sıra ailenin ön planda olduğu bir diğer husus da ailenin sosyal öğrenme sürecinin önemli bir parçası olmasıdır (Bandura, 1977). Sosyal öğrenme kuramına göre, bireylerin yaşamın erken yıllarında kurdukları çevresel etkileșimler modelleme aracılığıyla bilişsel süreçlerin yürütülmesiyle yakından ilişkilidir. Ailelerin baş etme stilleri, duygu ifadeleri ve davranışsal eğilimlerinin çocuk ve ergenlerin kullandığı duygu düzenleme stratejilerinin yordayıcılarından olduğu öne sürülmüştür (Morris vd., 2017).

Mevcut çalışmadan elde edilen sonuçlardan biri de, duygusal tepkiselliğin tepkisellik alt boyutunun yordayıcılarından birinin olumlu yeniden gözden geçirme olduğudur. Bilişsel duygu düzenlemenin alt boyutlarından biri olan olumlu yeniden gözden geçirmenin, olumsuz duygu durumunu ve olumsuz duygu ifadelerini azalttığı bulunmuştur (Gross, 2009). Yeniden gözden 
geçirme pratiği, olumlu duygu ifadesi ve daha yüksek seviyede iyi oluş ile ilişkili olduğu için işlevsel ve uygulanabilir bir duygu düzenleme stratejisi olarak kabul edilmiştir (Gross, 2002; John ve Gross, 2007). Çocuklarla yürütülen bir çalışmada, yeniden gözden geçirmenin endişe puanı yüksek ve düşük iki grupta da olumsuz duygulanımı azalttığı sonucuna ulaşılmıştır (Carthy vd., 2010). Gündelik yaşantıda kimi durumlarda bilişsel bir yorumu yeniden gözden geçirmek yerine kaçınma (dışarı çıkmaktan vazgeçmek) veya dikkatini dağıtmak (kendini sakinleştirmek için müzik dinlemek) gibi başka duygu düzenleme stratejileri kullanılabilir. İlgili alanyazında uyumsuz bilişsel duygu düzenleme stratejileri ve duygusal tepkisellik arasındaki negatif yönlü etkileşime işaret eden çalışmalar mevcuttur. Sırp bireylerle yapılan başka bir çalışmada, kendini suçlamanın negatif duygulanım için bir yordayıcı olduğu rapor edilmiştir (Popov, 2010). Kendini suçlama stratejisi bireylerin olumsuz durumlar karşısında kendine yönelik suçlayıcı düşünceleri ile ortaya çıkmaktadır. Duygusal tepkisellik ile ilişkisi incelendiğinde, bir başka uyumsuz bilişsel duygu düzenleme stratejisi olan düşünceye odaklanmanın tepkiselliği azaltarak olumsuz sonuçlara yol açabileceği vurgulanmaktadır (Zoccola vd., 2008). Düşünceye odaklanma stratejisi, olumsuz duygular üzerine sıklıkla düşünme ve eylemsizlik ile karakterizedir. Hilt vd.'nin (2014) düşünceye odaklanmanın duygusal tepkiselliğin uyum bozucu yönleriyle ilişkisini ortaya koyan bir çalışması mevcuttur.

$\mathrm{Bu}$ sonuçlardan hareketle; uyumlu bilişsel duygu düzenleme stratejilerinin olumlu duyguları ve tepkileri arttırdığı, uyumsuz bilişsel duygu düzenleme stratejilerinin ise psikolojik sıkıntı, öfke veya üzüntü gibi olumsuz duygulanımlarla ilişkili olduğu belirlenmiştir. Özetle, alanyazınla tutarlı olarak duygusal tepkisellik ile bilişsel duygu düzenleme ve algılanan sosyal destek değişkenleri arasında anlamlı ilişkiler bulunmuştur. Ek olarak, araștırma değișkenlerinin alt boyutlarından alınan puanların cinsiyetler arasında anlamlı bir farklılaşma içinde olduğu görülmüştür. Her çalışmada olduğu gibi bu çalışmada da bazı sınırlılıklar mevcuttur. Bunlardan ilki tartışma bölümünde ele alınan duygusal tepkisellik çalışmalarının bir kısmının öz-bildirim ölçeğinden çok fMRI (İşlevsel Manyetik Rezonans Görüntüleme) gibi beyin aktivitesini ölçen araçlarının kullanılmasıdır. Veri toplama süreci ile ilgili sınırlılıklar internet aracıllı̆ıyla toplanan bu verilerin kadın ve erkek dağılımının homojen olmaması doğrultusundadır. Gelecek çalışmalarda bu sınırlılık dikkate alınarak örneklem grubu genişletilebilir; ergenlik, erken yetişkinlik ve orta yetişkinlik gibi gelişim dönemlerini de kapsayacak șekilde incelenebilir.

Duygusal tepkiselliğin açıklanmasında algılanan aile desteğinin yanı sıra ebeveyn kabul reddi ve algllanan ebeveyn tutumu gibi çeşitli ailesel faktörlerin değerlendirilmesinin uygulamaya yönelik fayda sağlayabileceği düşünülmektedir. Algılanan aile desteğinin duygusal tepkisellik üzerindeki etkisinin ergenlik döneminde görülebilecek uyumsuz tepkiler değerlendirilirken koruyucu bir faktör olarak ele alınmasının faydalı olabileceği öngörülmektedir. Ebeveynlere 
yönelik psikoeğitim veya müdahale programları tasarlanırken çocuk ve ergenlerin duygusal tepkilerine çok boyutlu bir bakış açısıyla yaklaşmanın anlamlı olabileceğine inanılmaktadır. Bilişsel duygu düzenlemeye ait olumlu yeniden odaklanma ve plana yeniden odaklanma gibi stratejilerin duygusal tepkiselliğe etkisinden hareketle psikolojik iyi oluş ve psikolojik sağlamlık gibi değişkenler de denkleme alınarak kapsamlı bir model oluşturulabileceği düşünülmektedir. Araştırma bulguları göz önünde bulundurularak duygusal tepkiselliğin alt boyutlarının açıklanmasında uyumsuz bilişsel duygu düzenleme stratejilerinden düşünceye odaklanmanın etkisinin gelecek çalışmalarda psikopatolojilerle ilişkilendirilerek ele alınması önerilmektedir. 


\section{KAYNAKÇA}

Agoha, B. C. E., Ogwa, F., Evbuoma, K., Igbokwe, D., \& Idoko, J. (2015). Perceived social support, perceived stress as correlates of stress symptomatolog among university students. Covenant International Journal of Psychology (CIJP). Maiden Edition, 1(1), 27-34.

Aliche, J. C., Ifeagwazi, C. M., \& Eze, J. E. (2019). Emotional reactivity and surgical anxiety. The protective nature of perceived social support. Psychology, Health \& Medicine, 25(4), 434445. https://doi.org/10.1080/13548506.2019.1668030

Appleton, A. A., Buka, S. L., Loucks, E. B., Gilman, S. E., \& Kubzansky, L. D. (2013). Divergent associations of adaptive and maladaptive emotion regulation strategies with inflammation. Health Psychology, 32(7), 748-756. https://doi.org/10.1037/a0030068

Baltaş, Z. (2000). Sağlık Psikolojisi. Remzi Kitabevi, İstanbul, 133-165.

Bonanno, G. A., Papa, A., Lalande, K., Westphal, M., \& Coifman, K. (2004). The Importance of Being Flexible. Psychological Science, 15(7), 482-487. https://doi.org/10.1111/j.09567976.2004.00705.x

Bruhn, J. G., \& Philips, B. U. (1984). Measuring social support: A synthesis of current approaches. Journal of Behavioral Medicine, 7(2), 151-169. https://doi.org/10.1007/bf00845384

Bylsma, L. M., Taylor-Clift, A., \& Rottenberg, J. (2011). Emotional reactivity to daily events in major and minor depression. Journal of Abnormal Psychology, 120(1), 155-167. https://doi.org/10.1037/a0021662

Cai, W. P., Pan, Y., Zhang, S. M., Wei, C., Dong, W., \& Deng, G. H. (2017). Relationship between cognitive emotion regulation, social support, resilience and acute stress responses in Chinese soldiers: Exploring multiple mediation model. Psychiatry Research, 256, 71-78. https://doi.org/10.1016/j.psychres.2017.06.018

Campbell-Sills, L., \& Barlow, D. H. (2007). Incorporating emotion regulation into conceptualizations and treatments of anxiety and mood disorders. In J. J. Gross (Ed.), Handbook of emotion regulation (pp. 542e559). New York: Guilford Press.

Carthy, T., Horesh, N., Apter, A., Edge, M. D., \& Gross, J. J. (2010). Emotional reactivity and cognitive regulation in anxious children. Behaviour Research and Therapy, 48(5), 384-393. https://doi.org/10.1016/j.brat.2009.12.013

Carver, C. S., Scheier, M. F., \& Weintraub, J. K. (1989). Assessing coping strategies: A theoretically based approach. Journal of Personality and Social Psychology, 56(2), 267-283. https://doi.org/10.1037/0022-3514.56.2.267

Cassel, J. (1976). The contribution of the social environment to American Journal of Epidemiology. 104. https://doi.org/10.1093/oxfordjournals.aje.a112281

Cobb, S. (1976). Social Support as a Moderator of Life Stress. Psychosomatic Medicine, 38(5), 300314. https://doi.org/10.1097/00006842-197609000-00003

Cohen, S., \& Wills, T. A. (1985). Stress, social support, and the buffering hypothesis. Psychological Bulletin, 98(2), 310-357. https://doi.org/10.1037/0033-2909.98.2.310

Cook, E. C., Blair, B. L., \& Buehler, C. (2017). Individual Differences in Adolescents' Emotional Reactivity across Relationship Contexts. Journal of Youth and Adolescence, 47(2), 290-305. https://doi.org/10.1007/s10964-017-0673-9

Cunningham, M. R., \& Barbee, A. P. (2000). Social support. In C. Hendrick \& S. S. Hendrick (Eds.), Close relationships: A sourcebook (pp. 273-285). Sage Publications, Inc. https://doi.org/10.4135/9781452220437.n20

Cutrona, C. E. (1996). Social support in couples: Marriage as a resource in times of stress. Sage Publications, Inc. 
Davidson, R. J. (1998). Affective Style and Affective Disorders: Perspectives from Affective Neuroscience. Cognition \& Emotion, 12(3), 307-330. https://doi.org/10.1080/026999398379628

Diaz, T., \& Bui, N. H. (2016). Subjective Well-Being in Mexican and Mexican American Women: The Role of Acculturation, Ethnic Identity, Gender Roles, and Perceived Social Support. Journal of Happiness Studies, 18(2), 607-624. https://doi.org/10.1007/s10902-016-9741-1

Diener, E., \& Fujita, F. (1995). Resources, personal strivings, and subjective well-being: A nomothetic and idiographic approach. Journal of Personality and Social Psychology, 68(5), 926-935. https://doi.org/10.1037/0022-3514.68.5.926

Diener, E., \& Seligman, M. E. (2002). Very Happy People. Psychological Science, 13(1), 81-84. https://doi.org/10.1111/1467-9280.00415

Durkheim, E. (1897). Suicide, a study in sociology (1951 Edition, J. A. Spaulding, \& G. Simpson, Trans.). Routledge.

Eisenberg, N., Fabes, R. A., Murphy, B., Maszk, P., Smith, M., \& Karbon, M. (1995). The Role of Emotionality and Regulation in Children's Social Functioning: A Longitudinal Study. Child Development, 66(5), 1360. https://doi.org/10.2307/1131652

Eker, D., Arkar, H. ve Yaldız, H. (2001). Çok Boyutlu Algılanan Sosyal Destek Ölçeğinin gözden geçirilmiş formunun faktör yapısı, geçerlik ve güvenirliği. Türk Psikiyatri Dergisi, 12(1), 17-25.

Garnefski, N., \& Kraaij, V. (2007). The Cognitive Emotion Regulation Questionnaire. European Journal of Psychological Assessment, 23(3), 141-149. https://doi.org/10.1027/10155759.23.3.141

Garnefski, N., Kraaij, V., \& Spinhoven, P. (2001). Negative life events, cognitive emotion regulation and emotional problems. Personality and Individual Differences, 30(8), 1311-1327. https://doi.org/10.1016/s0191-8869(00)00113-6

Garnefski, N., Teerds, J., Kraaij, V., Legerstee, J., \& van den Kommer, T. (2004). Cognitive emotion regulation strategies and depressive symptoms: Differences between males and females. Personality and Individual Differences, 36(2), 267-276. https://doi.org/10.1016/S01918869(03)00083-7

Gohm, C. L., \& Clore, G. L. (2000). Individual Differences in Emotional Experience: Mapping Available Scales to Processes. Personality and Social Psychology Bulletin, 26(6), 679-697. https://doi.org/10.1177/0146167200268004

Gratz, K. L., \& Roemer, L. (2004). Multidimensional Assessment of Emotion Regulation and Dysregulation: Development, Factor Structure, and Initial Validation of the Difficulties in Emotion Regulation Scale. Journal of Psychopathology and Behavioral Assessment, 26(1), 41-54. https://doi.org/10.1023/b:joba.0000007455.08539.94

Gross, J. J. (1998). The Emerging Field of Emotion Regulation: An Integrative Review. Review of General Psychology, 2(3), 271-299. https://doi.org/10.1037/1089-2680.2.3.271

Gross, J. J., \& John, O. P. (2003). Individual differences in two emotion regulation processes: Implications for affect, relationships, and well-being. Journal of Personality and Social Psychology, 85(2), 348-362. https://doi.org/10.1037/0022-3514.85.2.348

Gross, J. J., Sheppes, G., \& Urry, H. L. (2011). Cognition and emotion lecture at the 2010 SPSP emotion preconference. Cognition and Emotion, 25, 765-781.

Hilt, L. M., Aldao, A., \& Fischer, K. (2014). Rumination and multi-modal emotional reactivity. Cognition and Emotion, 29(8), 1486-1495. https://doi.org/10.1080/02699931.2014.989816 
Jermann, Françoise; Van der Linden, Martial; d'Acremont, Mathieu; Zermatten, Ariane (2006). Cognitive Emotion Regulation Questionnaire (CERQ). European Journal of Psychological Assessment, 22(2), 126-131. https://doi.org/10.1027/1015-5759.22.2.126

Karasar, N. (2005). Bilimsel araştırma yöntemi. Nobel Yayıncılık.

Kring, A. M., \& Werner, K. H. (2004). Emotion regulation in psychopathology. In P. Philippot \& R. S. Feldman (Eds.), The regulation of emotion (pp. 359385). Mahwah, NJ: Lawrence Erlbaum Associates, Inc

Lazarus, R. S., \& Folkman, S. (1984). Stress, apraisal, and coping. Springer.

Lee, A. H., \& Woodruff-Borden, J. (2018). Roles of emotional reactivity, intolerance of uncertainty, and negative problem orientation on developing childhood worry. Personality and Individual Differences, 135, 25-30. https://doi.org/10.1016/j.paid.2018.06.048

Lepore, S. J., Evans, G. W., \& Schneider, M. L. (1991). Dynamic role of social support in the link between chronic stress and psychological distress. Journal of Personality and Social Psychology, 61(6), 899-909. https://doi.org/10.1037/0022-3514.61.6.899

Macgeorge, E. L., Samter, W., \& Gillihan, S. J. (2005). Academic Stress, Supportive Communication, and Health A version of this paper was presented at the 2005 International Communication Association convention in New York City. Communication Education, 54(4), 365-372. https://doi.org/10.1080/03634520500442236

Marroquín, B., Tennen, H., \& Stanton, A. L. (2017). Coping, emotion regulation, and well-being: Intrapersonal and interpersonal processes. In M. D. Robinson \& M. Eid (Eds.), The happy mind: Cognitive contributions to well-being (pp. 253-274). Springer International Publishing/Springer Nature. https://doi.org/10.1007/978-3-319-58763-9_14

Matsuda, T., Tsuda, A., Kim, E., \& Deng, K. (2014). Association between Perceived Social Support and Subjective Well-Being among Japanese, Chinese, and Korean College Students. Psychology, 05(06), 491-499. https://doi.org/10.4236/psych.2014.56059

Morris, A., Criss, M. M., Silk, J. S., \& Houltberg, B. J. (2017). The impact of parenting on emotion regulation during childhood and adolescence. Child Development Perspectives, 11(4), 233238. https://doi.org/10.1111/cdep.12238.

Nock, M. K., Wedig, M. M., Holmberg, E. B., \& Hooley, J. M. (2008). The emotion reactivity scale: development, evaluation, and relation to self-injurious thoughts and behaviors. Behavior Therapy, 39(2), 107-116. https://doi.org/10.1016/j.beth.2007.05.005

Norris, F. H., \& Kaniasty, K. (1996). Received and perceived social support in times of stress: A test of the social support deterioration deterrence model. Journal of Personality and Social Psychology, 71(3), 498-511. https://doi.org/10.1037/0022-3514.71.3.498

Oktan, V. (2005). Yalnızlık ve algılanan sosyal destek düzeyinin ergenlerdeki öfkenin gelişimine etkisi. Marmara Üniversitesi, Atatürk Eğitim Fakültesi Eğitim Bilimleri Dergisi, 21, 183-192.

Onat, O., \& Otrar, M. (2010). Bilişsel Duygu Düzenleme Ölçeği'nin Türkçeye uyarlanması: Geçerlik ve güvenirlik çalışmaları. M.Ü. Atatürk Eğitim Fakültesi Eğitim Bilimleri Dergisi , (31), 123 $-143$.

Pejičić, M., Ristić, M., \& Anđelković, V. (2018). The mediating effect of cognitive emotion regulation strategies in the relationship between perceived social support and resilience in postwar youth. Journal of Community Psychology, 46(4), 457-472. https://doi.org/10.1002/jcop.21951

Rabinowitz, J. A., Osigwe, I., Drabick, D. A., \& Reynolds, M. D. (2016). Negative emotional reactivity moderates the relations between family cohesion and internalizing and externalizing symptoms in adolescence. Journal of Adolescence, 53, 116-126. https://doi.org/10.1016/j.adolescence.2016.09.007 
Reti, T., de Terte, I., \& Stephens, C. (2021). Perceived social support predicts psychological distress for ambulance personnel. Traumatology. Advance online publication. https://doi.org/10.1037/trm0000331

Rosen, P. J., Milich, R., \& Harris, M. J. (2012). Dysregulated Negative Emotional Reactivity as a Predictor of Chronic Peer Victimization in Childhood. Aggressive Behavior, 38(5), 414-427. https://doi.org/10.1002/ab.21434

Rothbart, M. K., Sheese, B. E., Rueda, M. R., \& Posner, M. I. (2011). Developing Mechanisms of SelfRegulation in Early Life. Emotion review : journal of the International Society for Research on Emotion, 3(2), 207-213. https://doi.org/10.1177/1754073910387943

Sarason, B. R., Sarason, I. G., \& Gurung, R. A. R.(2000).Close personal relationships and health outcomes: A key to the role of social support.In B.R.Sarason \& S.W.Duck (Eds.), Personal relationships: Implications for clinical and community psychology. John Wiley.

Seçer, İ., Halmatov, S., ve Gençdoğan, B. (2013). Duygusal Tepkisellik Ölçeğinin Türkçeye uyarlanması: Güvenirlik ve geçerlilik çalışması. Sakarya University Journal of Education, 3(1), 77-89.

Shapero, B. G., Abramson, L. Y., \& Alloy, L. B. (2016). Emotional reactivity and internalizing symptoms: Moderating role of emotion regulation. Cognitive Therapy and Research, 40(30), 328-340. https://doi.org/10.1007/s10608-015-9722-4

Sobol, M., Woźny, M., \& Czubak-Paluch, K. (2021b). Emotion regulation and social support as related to depressive symptoms: A study of healthy and hospitalized adolescents. Personality and Individual Differences, 174, 110665. https://doi.org/10.1016/j.paid.2021.110665

Spinrad, T. L., Eisenberg, N., Harris, E., Hanish, L., Fabes, R. A., \&Kupanoff, K. (2004). The relation of children's everyday nonsocial peer play behavior to their emotionality, regulation, and social functioning. Child Development, 40, 67-80.

Stokes, J. P. (1985). The relation of social network and individual difference variables to loneliness. Journal of Personality and Social Psychology, 48(4), 981-990. https://doi.org/10.1037/0022-3514.48.4.981

Suri, G., Sheppes, G., \& Gross, J. J. (2013). Emotion regulation and cognition. In M. D. Robinson, E. Watkins, \& E. Harmon-Jones (Eds.), Handbook of cognition and emotion (pp. 195-209). The Guilford Press

Swickert, R. J., Hittner, J. B., \& Foster, A. (2010). Big five traits interact to predict perceived social support. Personality and Individual Differences, 48(6), 736-741. https://doi.org/10.1016/j.paid.2010.01.018

Thompson, R. A. (1994). Emotion Regulation: A Theme In Search Of Definition. Monographs of the Society for Research in Child Development, 59(2-3), 25-52. https://doi.org/10.1111/j.1540-5834.1994.tb01276.x

Udayar, S., Urbanaviciute, I., \& Rossier, J. (2019). Perceived Social Support and Big Five Personality Traits in Middle Adulthood: a 4-Year Cross-Lagged Path Analysis. Applied Research in Quality of Life, 15(2), 395-414. https://doi.org/10.1007/s11482-018-9694-0

Urano, Y., \& Ikeda, T. (2020). Perceived social support moderates the association betweenemotion regulation and psychological distress: a cross-sectional study among Japanese adults. Psychology, Health \& Medicine, 26(10), 1195-1205. https://doi.org/10.1080/13548506.2020.1802051

Vangelisti, A. L. (2009). Challenges in conceptualizing social support. Journal of Social and Personal Relationships, 26(1), 39-51. https://doi.org/10.1177/0265407509105520 
Wu, C., Li, S., Cheng, F., Zhang, L., Du, Y., He, S., \& Lang, H. (2020). Self-Identity and Career Success of Nurses in Infectious Disease Department: The Chain-Mediating Effects of Cognitive Emotion Regulation and Social Support. Frontiers in Psychology, 11. https://doi.org/10.3389/fpsyg.2020.563558

Yurdakul, A. ,Üner, S. (2015). Sağlık yüksekokulu öğrencilerinin duygusal tepkisellik durumlarının değerlendirilmesi. TAF Preventive Medicine Bulletin, 14(4). https://doi.org/10.5455/pmb.1-1422358166

Zhou, X., Wu, X., \& Zhen, R. (2017). Understanding the relationship between social support and posttraumatic stress disorder/posttraumatic growth among adolescents after Ya'an earthquake: The role of emotion regulation. Psychological Trauma: Theory, Research, Practice, and Policy, 9(2), 214. https://doi.org/10.1037/ tra0000213 


\section{EXTENDED ABSTRACT}

\section{Introduction}

Social support is defined as a structure that provides the social interactions which individuals need through the groups they feel or belong to and the relationships they have (Norris \& Kaniasty, 1998). In this respect, social support with both psychological and physical aspects is important. Perceived social support is a type of social support and refers to the availability of support resources when needed. People who perceived their social networks as supportive were found to be mentally and physically healthier than those who evaluated their networks less positively (Sarason et al., 2000). On the other hand emotional reactivity is considered one of the factors that determine the individual's readiness for emotional experiences, predisposition to experienced emotion, intensity and duration of emotion (Davidson, 1998; Gohm \& Clore, 2000). Cook et al. (2017) stated that one of the indicators of successful regulation of emotions in maladaptive experiences is emotional reactivity. Considering the effect of emotion regulation on changing the individual's cognitive evaluations of negative emotions and reactions to emotions, it is thought that the use of adaptive strategies may contribute to psychological well-being. The main motivation of the research is to contribute to the literature by revealing how the social support perceived by university students and the cognitive emotion regulation strategies they use affect their emotional reactivity levels.

\section{Method}

This study was conducted as a correlational study in Turkey between November and December 2021. The sample of study consisted 400 university students ( $F=262, M=138)$. Ttest, Pearson correlation analysis and multiple linear regression analyzes were used due to the normal distribution of the data. Data collection forms including sociodemographic form, Emotional Reactivity Scale (ERS), Cognitive Emotional Regulation Scale (CERS) and Multidimensional Scale of Perceived Social Support (MSPSS) were used to collect data.

\section{Results}

In the t-test results to find gender differences, it was concluded that the emotional reactivity levels of men (Mean=2.77, $\mathrm{SD}=.61)$ were higher than the reactivity levels of women (Mean= 2.61, $\mathrm{SD}=.71)$. Also, men are more likely to refocusing on the planning and women have higher levels of putting into perspective and catastrophizing. According to the correlation analysis, it was concluded that there is a significant relationship between cognitive emotion regulation sub-dimensions and perceived social support sub-dimensions. For the results of the 
regression analysis, it was found that the sub-dimensions of cognitive emotion regulation predict the sub-dimensions of emotional reactivity regulation.

\section{Discussion \& Conclusion}

As a result of this study, there is a relationship between emotional reactivity with cognitive emotion regulation and perceived social support. In the study examining the relationship between perceived social support and cognitive emotion regulation, it was found that there was a positive correlation between the sub-dimensions of perceived social support and the sub-dimensions of cognitive emotion regulation (Pejičić et al., 2018). This current study was consistent with past research findings. Similar results were obtained between the subdimensions of cognitive emotion regulation and the sub-dimensions of perceived social support. In current study, a significant relationship was found between the perceived social support and emotional reactivity. A similar study supporting this result, the effects of perceived social support, surgical anxiety and emotional reactivity were investigated (Aliche et al., 2019). Surgical anxiety was found to be low in situations where the high social support received was higher than the high emotional reactivity. Based on the results in the literature, it can be concluded that adaptive cognitive emotion regulation strategies increase positive emotions and reactions, while maladaptive cognitive emotion regulation strategies are associated with negative emotions such as psychological distress, anger or sadness, and it can be assumed that the types and forms of social support that the individual can access may change over time. At the same time, these cognitive emotion regulation strategies can affect emotional reactivity. It was found that cognitive emotion regulation strategies predict positive reappraisal, rumination, positive refocusing, putting into perspective, and refocus on planning predict the subdimensions of emotional reactivity in the current study. It can be said that individuals with a high level of perceived social support use maladaptive cognitive emotion regulation strategies less as a result of the feedback they receive from their environment by the influence of the context. At the same time, these individuals can show their emotional reactions according to the cognitive emotion regulation strategy they use. 